\title{
Drones, Swarms and Becoming-Insect: Feminist Utopias and Posthuman Politics ${ }^{\mathrm{i}}$
}

In her 1915 feminist utopian fiction Herland, Charlotte Perkins Gilman imagined an all-female society that had evolved to reproduce without men as characterized by decidedly insect-like aspects. Narrated by men who stumble upon their community, the story describes women who prove inscrutable to some of the male explorers: a community whose strength was as "a multitude actuated by a common impulse" (Perkins Gilman, 2015[1915], p.56). The society these women had created, with the ability to reproduce without men, was a society free from war, violence, and poverty. Women-as-insects is a theme that runs through this text, with, as in Haraway's invocation of "inessential fathers" (Haraway, 1991, p.151), that "among insects we find [fathers] of less importance, sometimes very little" (Perkins Gilman, 2015[1915], p. 62-63). One of the men compares the community to an anthill and a beehive because of their cooperative nature and the way the young are communally raised. The cooperative nature of the women's utopia is juxtaposed to the competitive, hierarchical masculine order (ironically by one of their own who came to accept and defend the way of life in Herland): "Ants don't raise their myriads by a struggle do they? Or the Bees?” (Perkins Gilman, 2015[1915], p.132). What appears as a utopia for the women becomes an unbearable dystopia for the men who cannot reconcile themselves to a life of equality with women.

James Tiptree Jr.'s Houston, Houston Do You Read? (1989[1976]) is another classic work of feminist science fiction that presents another narrative of three men encountering an all-female society. However, these men are space explorers who have skipped ahead in time to a post-apocalyptic earth in which the survivors are all women, of different races and ethnicities, working communally with little conflict. What appears as a dystopia to the men exists as something else for the survivors of this world - not quite utopia, but a world functioning well enough without sexual conquest or the hierarchical leadership of men. These women, who have reproduced for centuries by cloning, are also represented as 'insect-like': a female astronaut in a space suit is 'a silvery spider on a training thread' (1989[1976] p. 46), while a male survivor likens the women's talk to that of ants or bees, 'twiddling their antennae together every time they meet' (53). After feeding the men a chemical 'truth-serum' that exposes the men's rapacious and dominating thoughts and plans, the women deem these male anachronistic astronauts too dangerous to integrate into this all-female form of humanity and have them killed. 
Woman as insect is a trope in feminist science fiction works that make a more positive association between women and insect life. Graham Murphy details the sci-fi trope of the matriarchal utopias likened to hives, anthills or colonies in science fiction, unconcerned with filiation and patrilineal descent. For Murphy, 'becoming-insect' is site for non-heteronormative, utopian configurations that embraces the multiplicity and indeterminacy the insect represents because of its radical difference (Murphy, 2008). Men in these scenarios often can't cope, cannot embrace the 'becoming-insect,' seeing it as a site of existential threat. This figuration of the insect and of a feminist utopia bearing a resemblance to the social life of insects in 'swarms' in particular, is quite at odds with a contemporary materialization of insect life and the 'swarm' in particular, in its manifestation as 'drone swarm' technology at the forefront of military technologies.

Contemporary developments in artificial intelligence and warfare suggest that the future of warfare will not be 'robots' as technological, individualized substitutions for idealized (masculine) warfighters but warfighters understood as swarms: insect metaphors for non-centrally organized, self-organizing problem solving. The swarm is not 'merely' a metaphor but the organizational basis for military tactics. As famously argued by John Arquilla in a RAND study "Swarming and the Future of Conflict," swarming is to be the future of war fighting tactics in the US. Swarming decentralizes forces operation in a way that values mobility, unique autonomy, and real-time continuous communication (Arquilla and Ronfeldt, 2002; Kosek, 2010, p. 664). The current trend toward the development of swarming technologies in which artificially intelligent 'mini drones' communicate with each other to move in random, non-linear ways is does not only blur the lines between human and technology in the 'posthuman' but between the human and animal, and animal and technological. In 2006, the US Defense Advanced Research Projects Agency (better known as DARPA) launched a call for scientists in the US to submit "innovative proposals to developed technology to create insect-cyborgs" (Anthes, 2013). "Bio-mimetic" technologies are considered the future of warfare and metaphor of the swarm is increasingly displacing the individualized human body as the model of artificial life.

I've elsewhere argued that precision warfare in general, and drone warfare more specifically, blur lines between human and technology in warfare in the form of posthuman bodies (Wilcox 2015, 2017). The posthuman, as explored by feminist theorists such as Donna Haraway, N. Katherine 
Hayles, and Rosi Braidotti, is a process of formation and reformation that reworks and undermines essentialist notions of culture and nature, biology, and technology. Cybernetics and artificial intelligence, I've argued, were developed as means to win wars, but they end up redefining and reorganizing the boundaries of the human body in and through both imbrication in technology and in relation to other (killable) bodies. The challenge the cyborg or posthuman body poses is not the addition of new technological advances to an already-existing human body, but of a body that is always already formed through norms and relations to others, whether these other are human, technological, or animal. The 'swarm' as a posthuman figuration that defies technological/animal/human categorization appears to be a relatively new site of the development of (political) technologies of warfare, rather than a figuration of peaceful communal living. As a figuration that shapes the conduct of war and political violence, it demands new conceptualizations of the relationship between war and gender that displace the overarching critique of masculinism for a more troubled and troubling posthuman and queer notion of the operation of gender in war.

While the swarm's ability to coordinate without central command could suggest a 'feminized' way of approaching war (see Manjikian 2014 for example), I would suggest a queer reading of the posthuman drone swarm in Weber's (2016) terms, following Sedgwick (1993), in which 'queer' means a failure to signify gender monolithically (see also Daggett 2015). As such, I argue that the drone swarm has a deeply ambiguous relationship between signifiers of masculinity and femininity. My queer reading of the drone swarm is also influenced by the ways in which forms of animal and otherwise non-human life have played a key role in queer theorizing in recent years. The monstrous, abjected, non-human and more-than-human have been sites of appropriation for queer and transtheorists; from Susan Stryker's trans-theory invocation of Frankenstein (Stryker 1994, although see Stryker 2015) to Halberstam's inspiration by animated animals (2011) and Chen's exploration of animality, race, and queerness (2012) among others.

Furthermore, the drone swarm is also its own component of a queer, necropolitical assemblage in which the "feminine" imaginary of insectoid life and the swarm becomes a core component of weaponised technologies. The figuration of the swarm thus exemplifies a 'queer necropolitics' (Haritaworn, Kuntsman and Posocco, 2014) that builds upon Puar (2007), Reddy (2011) and other's work to analyse gendered, national, and racial formations that operate under logics of sexuality to 
produce differential worlds of life and death. Here, understanding the term 'queer' as detached from gay or lesbian identity but rather as 'assemblage' calls attention both to the formation of a 'terrorist' subject as queer, as well as a method of being "attuned to movements, intensities, emotions, energies, affectivities and textures as they inhabit events, spatialities and corporealities" (Puar, 2007, p. 215). Puar's appropriation of the Deleuzian term 'assemblage' for her invocation of 'queer assemblages' (2007) is put into productive tension with models of intersectionality which presumes that the constituent elements in identity models such as gender, class, race, and sexuality can be disassembled. Such methods seek to shed light upon the 'queerness' already present in the world in terms of exclusions/inclusions, brutalities and differing regimes of living and dying (Haritaworn, Kuntsman and Posocco, 2014) while at the same time also seek to broaden queer analyses to include ongoing engagements with shifting identifications, desires, affects, and emotions that shape global politics. The politics of the swarm can be considered a kind of 'murderous inclusion' or a kind of 'queer necropolitics'. The figurations of insect and swarm no longer only represent a light of flight outside of the masculinist politics of control but also are currently being appropriated for a necropolitics of surveillance and warfare.

In investigating 'the swarm' in its contemporary manifestations, I follow Haraway's (1997) conception of the figuration. Figurations are semiotic tropes combining knowledge, practice, and power that shape the maps of our world and how we understand relations in the world. "Figurations are performative images that can be inhabited" (Haraway, 1997, p.11). Figurations, in Cynthia Weber's recent summary, "emerge out of discursive and material semiotic assemblages that condense diffuse imaginaries about the world into specific form or images that bring specific worlds into being" (Weber, 2016, p. 28). Importantly, "figures must involve at least some kind of displacement that can trouble identifications and certainties" (Haraway, 1997, p.11). Figurations are thus "living maps" in Braidotti's terms (2002, p. 2) and are not totalities but subject to revision and reconfiguration.

In considering 'swarm' as a figuration, I take seriously Haraway's perspective in which myths and stories about cyborgs, insects, and women are "sociobiological stories depend on a high-tech view of the body as a biotic component or cybernetic communications system," and for which "sex, sexuality and reproduction are central actors in high-tech myth systems structuring our imaginations of personal and social responsibility" (Haraway, 1991, p. 169). Such an analysis would require more 
than a critical feminist reading of the ways in which sex, gender, sexuality, reproduction are imagined in cultural products such as literature and film. Feminist science fiction can become a 'cyborg story' of recasting the 'myths' and technologies in subversive ways, as neither cyborgs nor swarms are determined by their origins. At the same time, insects and their collective life including the figuration of the 'swarm' are not only a set of myths or representations, but a form of materialization, most prominently in military technologies and their practices in necropolitical forms of death-dealing. In thinking through science fiction, feminist and otherwise, I want to follow Haraway in understanding "myth and tool mutually constitute each other" (Haraway, 1991, p. 164), or what N. Katherine Hayles describes as a double vision that "looks simultaneously at the power of simulation and at the materialities that produce it" in order to "better understand the implication of articulating posthuman constructions together with embodied actualities" (Hayles, 1999, p. 47, emphasis in original). Privileging neither nature nor culture in their on-going mutual becomings, I want to further develop the project of relating feminist readings of science fiction to feminist materialist analyses of becoming-insect not in the service of utopian projects but rather to point toward heterotopic worlds of difference and multiplicity that are up to the task of theorizing the dystopic necropolitical worlds embodied by swarming drones.

In the following exploration of the figuration of the swarm, particularly its insectoid manifestations, I begin by discussing its linkages to femininity and 'becoming-woman' and to racialized forms of life deemed killable; I then turn to the ways in which the figuration of the swarm is inspiring a new generation of military weaponry that served as 'technologies of racial distinctions' (Allinson 2015). In light of this appropriation of imagery and material forms associated with femininity and certain forms of feminist politics, I then describe the figuration of the swarm as deeply ambivalent in terms of its politics of gender, race, and sexuality before turning to ways in which insect and swarm imagery are being re-imagined in ways that transcend the contemporary militaristic politics of the swarm.

\section{Insects and "Becoming-Woman"}

In an influential book, Barbara Creed (1993) argues that there is a relationship between 'becominginsect' and 'becoming-woman' with insects representing monstrous feminine bodies that pose a threat to the masculine order. ${ }^{\text {ii }}$ Creed identifies the 'monstrous feminine' as a gothic trope and staple 
of the horror genre. The monstrous-feminine is typified by the alien $\mathrm{m} /$ other in Ridley Scott's Alien trilogy, especially in terms of the fluid, 'gooiness' described by Julia Kristeva as abject (1982); that which refuses to conform to bodily boundaries, that which is expelled in order to create the illusion of the bordered boundary (see also Wilcox, 2015 pp. 80-103). More than a century ago, Belgian playwright Maurice Maeterlinck described the 'insect uncanny,' that fascination and horror of the insect: "The insect brings with him something that does not seem to belong to the customs, the morale, the psychology of our globe. One would say that it comes from another planet, more monstrous, more dynamic, more insensate, more atrocious, more infernal than ours" (Shaviro, 1995, p. 54). Insect life is abject. “...it is primordially ambivalent: it arouses both disgust and desire, at once demanding and repelling our intimate contact...insect life is an alien presence that we can neither assimilate nor expel (Shaviro, 1995, p. 47). The insect (or more broadly, the 'bug,' which refers to insects and creatures technically classified as arachnids such as spiders) suggests the limits of human control over the environment: "Bugs are the stumbling block that reveal the fatal flaws of our fantasies of seamlessness and conformity. They carry within them the image of a world that exceeds our control and therefore they promise destruction" (The New Inquiry, 2016). The insect body poses the threat of radical otherness in biological terms and of 'being' in the world. No wonder that 'alien' societies are often represented in insect form, as are racialized populations conceived of as outside of the order of the 'human' and perceived as threatening the dominant racial order. The horror of insects and relatedly, of the swarm, is also of female reproduction outside of patriarchal control: that fathers are 'inessential' (Haraway, 1991, p. 151). In particular, the praying mantis is associated with femininity, female sexuality, and the fantasy of the vagina dentate: a femme fatale writ small (Grosz, 1995). ${ }^{1}$

In the genre of science fiction, insects, swarms and hives represent a continual source of terror, whether against female sexuality and reproduction or Communist hordes threatening individualism (Jackson and Nexon, 2003). Wars are frequently fought against insect-like interstellar aliens such as in Robert Heinlein's Starship Troopers and Orson Scott Card's Ender's Game, and the Borg on various Star Trek incarnations. The alien-mother of Ridley Scott's Alien is insect-like. Woman as becominginsect is a fearful spectre in many works of science fiction that is often portrayed negatively as a

\footnotetext{
${ }^{1}$ The image of female praying mantises as sexual cannibals appears to be driven in large part by the projection of human gender stereotypes on animals as well as manipulated laboratory conditions. Thanks to an anonymous review for this insight. See (Entomology Today, 2013).
} 
warning against tampering with uncontrollable forces of nature represented by the threat of reproduction uncontrolled by masculine sovereign power. Kurt Neumann's 1958 cult classic The Fly and Star Trek's 'Borg', are two other examples of insect life linked with the threat of 'becomingwoman' that are also exemplars the way in which 'insects signal a high degree of imbrication of the organic with the technological" (Braidotti, 2002, p. 152). As Braidotti notes, "insects are only the most evident metaphorical process conflating a number of irreconcilable terms such as life/nonlife, biology/technology, human/machine” (2002, p. 277) although for Braidotti the insect is situated closer to the 'posthuman' and the technological than with the actual animal kingdom (see Braidotti, 2002, p. 149).

One classic example of the insect as abject form of humanity is Kurt Neumann's 1958 cult classic The Fly in which a scientist invents a machine to solve a logistical problem: to move items from one place to another with electricity. Life here was a problem: living creatures couldn't go through the machines without being 'reprogrammed' in a devastating way. Testing the process on himself, the scientist accidentally splices himself with a fly. His head and arm become 'fly-like' and the fly has a miniature head of a man. After his wife is unable to capture the smaller fly, the mostly-scientist feels himself 'becoming-insect' in terms of losing his intellect, typing to his wife that his 'brain thinks strange things now' and that he 'feel[s] my will going already'. Fearing his loss of reason and agency, he attacks his wife, famously viewing her image in multiplicity in kaleidoscope vision before he enlists his wife's help in killing himself. Ultimately this killing was accepted as legitimate when the detective investigating the scientist's death killed the human-headed fly begging for help as he/it lay trapped in spider's web. To assuage the wife's guilt, the scientist/fly's brother argued that if killing one was acceptable, so was the other. Neither was human and thus neither was a death that counted as a murder. Becoming-insect is an effect of uncontrollable scientific discovery of the nuclear age, tying the patriarchal scientist's inability to master the reproduction of life with the fear of the feminine multitude and loss of the omnipotent, unitary masculine reason of the sovereign Enlightenment subject. Becoming-insect blurs the line between the sovereign One and the insect multitude, a thought so frightening that such figures become 'bomines sacri' (Agamben, 1998) whose deaths do not count as murders.

Image 1: The bug's eye view in The Fly (1958). 
Swarms that are less self-organizing and that resemble a sovereign leader of a collective include the feminine 'queen' of the 'buggers' (note the reference to queer sexuality), later known as the Formics (as in the family of ants Formicidae) from Ender's Game by Orson Scott Card and the hive queen of the Borg from various Star Trek incarnations, most notably Voyager. In Star Trek: The Next Generation (1987-1994) we are presented with the Borg as the ultimate other to liberal individualism: a multitude of voices speaking as one with threats of assimilation and annihilation. This is a vision of the horde with no individuality and no central control. Later, the Borg are revealed to be cyborgs, different individuals assimilated into the Borg collective by means of technological prostheses that not only give them super-human strength and capabilities, but allow them to adapt and learn from the experiences of other units in the Borg. The Borg Queen is somewhat ambiguous; in First Contact she is represented as embodying the collective consciousness of the hive, but in ST: Voyager (19952001) she is clearly a leader, imperiously giving orders, even acting against the will of the collective: a femme fatale. There is also a utopia here in the 'dream world' of Unimatrix Zero. This is a place free from the hive mind that Borg could visit while regenerating. A device attached to all Borg as part of their assimilation make it possible for them to enter this haven, in which they could adopt their preassimilation appearance, as similar members of a species, lacking the many technological prostheses that define these cyborgs and keep them connected to the hive. These Borg 'drones' had no memory of Unimatrix Zero until the Voyager crew introduces a 'nanovirus' to enable 'drones' to keep their memories of Unimatrix Zero, which leads to the Borg Queen retaliating in such a way that Borg 'drones' become independent outside of Unimatrix Zero and the Queen herself. Utopia exists within the cybernetic space that is imaged as outside of that very space that makes it possible in the first place, yet this utopia is imaged in a liberal humanist vein of non-prosthetic, naturally given individuality that is taken as the subject of agency and emancipation In the Borg Queen we are presented with a vision of the female insect-like cyborg, of which Jack Halberstam writes, "The female cyborg, furthermore, exploits a traditionally masculine fear of the deceptiveness of appearances and calls into question the boundaries of human, animal, and machine precisely where they are most vulnerable - at the site of the female body" (Halberstam, 1991, p. 440). Halberstam links the fear of autonomous technology and its association with sophisticated weaponry to the gendering of technology as feminine: represented as demonic threats and as harbingers of chaos and destruction. Fear of autonomous machines is linked to an equation of artificiality with a loss of an essential self. "The machine itself was seen to threaten the hegemony of white male authority because it could as easily be used against a government as for it; autonomy was indeed its terrifying 
potential" (Halberstam 1991, 439). The cyborg-insect hive of the Borg recalls the threat of female power and female reproduction uncontrolled by men, a mode of being considered to be existentially threatening to humanity itself as to be represented as outside it its boundaries. While still understood to be outside of the boundaries of humanity, the figuration of the insectoid swarm is contemporarily being appropriated in the services of racialized productions of spaces of life and death.

\section{Swarms of War}

The swarm as a figuration is currently undergoing a material transformation, as it has become in the past few decades a transformative model underpinning military technological and tactical innovation. As mentioned previously, the swarm is defined by self-organizing capabilities that are non-linear and depend upon the adaptive coordination of individual bodies that are not necessarily commanded by a sovereign source. While swarming tactics have been part of the repertoire of war fighting for centuries, if not longer, what distinguishes the emerging military manifestations of the swarm are that they are configurations of humans, technological artefacts, and various artificial intelligence capacities, as well as the fact that they are driven in part by the perception of a changing threat environment for the US and other advanced industrial states of threats that do not only stem from conventional state military forces or nuclear weapons, but more mobile and unpredictable threats. Swarms are seen the evolutionary stage from networked warfare, as they are more adaptable and fluid, based on biological models rather than the static model of a network (Scharre 2014). The idea behind the drive to harness the material capabilities of the swarm is that bees, ants, and such are not individually intelligent, but can collectively exhibit much more complex behaviour. In laboratories and bases, the US, UK and other militaries are developing what the US military has called SWARM capability, or "smart warfighting array of reconfigurable modules." A key advantage that swarm intelligence is thought to enable is ability for an entire swarm to be controlled or directed by a single operator, rather than a vast network, while another advantage is the ability to adapt and communicate in real time, beyond the ability of humans to process and respond. The vision of the drone itself, in its most famous manifestation as "Predator" or "Reaper" can be seen as a kind of insect vision. The multiple lenses in the drone swarm are about to provide greater 'situational awareness' and monitor the environment from many different angles (see Chamayou, 2015, p. 38). 
Another advantage held out for the technological swarm is that the swarm will not be affected by losses and casualties in the same way that human combatants are (Hambling, 2015, chap 7). The US Navy is developing low-cost swarming drone technology in its LOCUST program, with the aim of having 30 drones flying together without having to be individually controlled (Hambling, 2015, chapter 7). To develop these capacities, many different kinds of 'microdrones' are being developed (see also Bumiller and Shanker, 2015; Thielman 2015). Inspired by nature's ability to create smallscale flying machines, these many kinds of 'insect cyborgs' are primarily sought to provide surveillance: they are to be mobile 'bugs'. Scientist Vijay Kumar at the University of Pennsylvania, for example, studies insects to learn principles upon which ants divide labour to perform different tasks in order to someday apply these principles to program a fleet of aerial robots to interact with each other toward a common goal (Conner, 2014). Rosi Braidotti describes a "techno-beastiary" of military developments such as $5 \mathrm{~kg}$ 'Sand Fleas' that can leap through window or off 30 meter ledges while stabilizing and filming, six-legged robo-cockroaches that can climb walls, and a DelFly, a dragonfly-shaped surveillance drone with a camera weighing only a few grams (Braidotti, 2013, p.124). Some 'insect-cyborgs' are not technological reproductions of insect life, but modifications of insects themselves: the "Beetle Commander" is a wired-up flower beetle controlled by signals sent to its brain via a backpack including a radio receiver, battery, custom built signal board connected to electrodes in the Beetle's brain (Anthes, 2013) iii. The UK government's Ministry of Defence has also recently announced a competition for funding for the development of technologies for drone swarms of over 20 components that could be operated by a single operator (Gov.uk, 2016). The US is adapting its popular f-16 fighter jet to allow a pilot to operate unmanned vehicles along side it, as well as to deploy a swarm of drones (Axe, 2016). The capacities of insect life and the relations of the swarm are clearly no longer only a source of threat and danger but a means by which that perceived threat is contained.

The swarm, as represented in a figuration linking it to 'becoming-woman' poses a threat to the political ontology of the 'body politics' and thus to political order. The biological swarm, the technological network, the political multitude are variations of an ambivalent negotiation of a political body that bears a similarly ambivalent relationship with sovereignty (Thacker, 2004a, 2004b). The agency of the swarm is unclear; it emerges out of interactions between individuals, in response to environmental constraints, and within groups, according to studies of animal behaviour going back to the $19^{\text {th }}$ century (Thacker, 2004a). But now it is also multiplicity that is used on behalf 
of sovereign power and necropower. While Hardt and Negri celebrate the swarm as a network of multitude of different creative agents solving problems without centralized control (2003, pp. 91-92), the mere existence of a network does not necessarily make it more democratic. As Galloway and Thacker have argued (2007) some swarms are compatible with centralized control; that is, swarms may be controlled or directed, or a swarm can be used for the purpose of control itself (see also Coeckelbergh, 2011). The swarm occupies an ambiguous categorization between the 'many' and the 'one' in terms of individual independence and collective coordination. This figure of the 'swarm' has much in common with Lauro and Embry's articulation of the 'zombie' (2008) in its indeterminate status between living and dead and in its posthuman consciousness that obliterates the distinction between subject and object (Lauro and Embry 2008).

The inspiration and development of 'drone swarms' is reminiscent of the creation of the feminine automaton, such as in Metropolis (1927) or Ex Machina (2015) machines created in feminine bodies designed to do men's bidding. A key critique of automated drones guided by artificial intelligence, including drone swarms, is the potential or anticipated loss of human control over the technologies of death. Part of the fear here in alleged loss of humanity in warfare is better theorized as the loss of an ideal of humanity associated with a certain form of masculinity: namely, the possessive liberal individual, whose agency is secured in a conscious mind (Hayles, 2005, p.177; Hayles, 1999). As N. Katherine Hayles notes in her work My Mother Was a Computer (2005), the persistence of gendered representations of artificial intelligence, in which a male creator exacts his will through the use of female automata (female bodies controlled by another agent) against other men. This cultural trope is being realized in the creation of 'drone swarms': mechanical creations made to mimic insect and other forms of swarming life in the service of militaristic ends. It seeks to harness the feminized power of the swarm for its own ends.

As such, the swarm is now not only a metaphor but a central mode of biopolitical, and necropolitical life. Foucault's biopolitical analysis of the emergence of different modalities of power revolves around a relationship with certain non-human forms of life/death in the form of disease-causing microbes and viruses; from the sovereign exclusion of infected bodies of leprosy to the discipline and surveillance of the plague, to the regulation of different kinds of circulations of people and nonhuman objects in the 'milieu'. Our contemporary biopolitical analysis requires an analysis of the politics of life and death in the insect and the swarm, which, following Braidotti, cannot be assumed 
to be a mere metaphor or representation for political life but an animating materialist logic (2002). The issue of the swarm that defies categorization between the one and the many of which sovereignty depends is a central problem for political organization. As Thacker writes, "In the 'problem of multiplicities' presented to the body politic concept by plague, pestilence, and epidemic, multiplicity is never separate from, and is always inculcated within, the problem of sovereignty....it is multiplicity that plagues the body politic" (Thacker, 2011, p.154, emphasis in original).

Much of the debate about drone warfare has focused on prospect of 'killer robots' being deployed and the lack of human control over the sovereign power of killing. Defenders of the use of artificial intelligence and automated targeting point to the benefits, such as the removal of emotion and human error that can result in increased deaths of civilians (see inter alia Byman, 2013; Lewis 2013; Strawser 2010). Regardless of the merits of such arguments, the drone and increasingly, drone swarm tactics, constitute the terrain of war and the subjects who both wage and suffer from war. Eyal Weizman notes that the swarm plays a key role in the tactics of Israel ground forces (2011). Achille Mbembe writes, "in our contemporary world, weapons are deployed in the interest of maximum destruction of persons and the creation of death-worlds, new and unique forms of social existence in which vast populations are subjected to conditions of life conferring upon them the status of living dead' (Mbembe, 2003, p. 40, emphasis in original). His thesis amends Foucault's biopolitical concept and formulates contemporary politics as not only biopolitical but also necropolitical. The lines between war and politics are blurred as they are in biopolitics, but power does not only "make life live" but creates certain categories of the living dead, as those always already dead, subject to massacre.

In $19^{\text {th }}$ and early $20^{\text {th }}$ century social evolutionary theory, studies of insects played a key role in naturalizing racial and colonial hierarchies from readings of colonialism and slavery as present in insect 'societies', as well as the classification of certain insect societies as more or less like humans. "The social construction of insect sociality was premised on colonial views of what defined civilization as the "highest" and all others as "lower" in the social scale" (Rodgers, 2008, p. 139). While the colloquial term of the 'drone' is taken from ethology itself as a signifier of a zombie-like non-cognition, the place of the insect between life and death takes on new meaning in contemporary global violence. The militarized techno-swarms created on behalf of a project of biopolitical warfare in which ability to fight war without risk of death to human subjects on one side, while entire 
populations "li[v]e under drones," in which the 'buzzing' sound of drone is a source of anxiety and fear. One member of a community in Pakistan affected by drones described the effect sound of drones buzzing overhead as a 'wave of terror' coming over the community: "Children, grown-up people, women, they are terrified...they scream in terror" (Stanford International Human Rights \& Conflict Resolution Clinic, 2012). Allinson describes the drone as 'a technology of racial distinction' as it is an apparatus of deciding whose live is worthy of living and who is to be put to death (Allinson 2015, 120), its development and usage take place as part of the reconstitution of the theater of war as a frontier zone of American empire, a processes that has, in Feldman's words, "contorted the temporality of warfare through notions of preemption and endurance, recalibrated Orientalist imagined geography through far more porous concepts of proximity that challenge received notions of state territoriality and national borders, and fixated on the mystique of 'precision targeting' in highly ambiguous structures of race and space' (Feldman 2011, 329). The description of people killed by drones as 'bug splats' ${ }^{\text {iv }}$ in military slang further signifies the dehumanization and abjectification of those killed by drones, whether targeted or accidentally killed. ${ }^{\mathrm{v}}$

Figurations of the swarm here are used as instruments of sovereign power to kill and manage other populations figured as inhuman 'swarms'. The threat of terrorism is figured as the threat of the multitude, of the swarm, the concerted action that does not necessarily have a single head. The (former) US spokesman coordinator for counter-terrorism, Cofer Black, claimed "the threat of international terrorism knows no boundaries" (Black, 2013 [2003]). The threat of terrorism often represented as boundless and formless. The purported formlessness of such loosely connected organizations is also due to their transnational organization of various 'terrorist groups'; this, combined with their tendency to make use of territories that are beyond the reach of the administrative power of various states, means that the contemporary figure of the 'terrorist' is dangerous in part because of his (or increasingly, her) lack of subjectification in the terms of state power and state identity. While marked by difference in this way, they are also able to hide this difference. The terrorist, like the communist or homosexual, could be anybody, hiding in a 'sleeper cell', blending in with the population by various forms of deception, such as shaving their beards. Al-Qaeda in particular has been conceptualized as a network or more specifically, as individuals who become radicalized and who act in the name of Al-Qaeda with no other formal affiliation. It is a collective that acts without a hierarchy. In this sense, the 'enemy' is represented in insect ways as well. In the shift to war technologies and tactics inspired by insect swarms, we may be seeing a final 
admission that traditional modes of warfare are not always able to control non-hierarchical, feminine/queer and networked spaces. ${ }^{\text {vi }}$

The figuration of 'swarm' has also been applied to refugee and migrant populations, most famously by former UK Prime Minister David Cameron. Rhetorically figured as swarms, refugees threaten to overwhelm like a plague of locusts. Even without using the specific language of swarm, refugees have been depicted as reproducing uncontrollably, threatening to overwhelm, disturb order, and defy boundaries. This is a common figuration of the masses, multitudes, rioters and such that fall back onto the monstrous as threatening other. Yet, unlike these feminine creations, the entire purpose of the techno-swarm is that they are not controlled or controllable by man: "Swarms may not be predictable to the enemy, but neither are they exactly controllable or predictable for the side using them, which can lead to unexpected results... a swarm takes action in its own" (Singer, 2009, p.110). The unpredictability of the swarm is at once its greatest promise and its peril.

\section{Ambivalence of the Swarm}

Insect life and the swarm remain deeply ambivalent figurations. As noted in the feminist works of utopian and speculative fiction from the introduction, the insect and particularly the collective insect life of the swarm have been claimed by some feminists as a positive mode of being to emulate, in distinction to the view of women-as-insect that characterize the alien monsters of the genre. However, Jinathana Haritaworn (Haritaworn, 2015) has recently questioned the celebratory nature of queer scholarship taking up monstrosity, animality and morbidity as objects of regeneration and nostalgia, particularly when 'queer' intersects with racialization and the necropolitical. The current wave of militarizing the swarm suggests the need for a similar cautious approach to tease out the implication of insect/swarm figurations. The symbolic ambiguity of the drone swarm is perhaps most starkly seen in the use of drone swarm to fly in formation to create the image of an American flag at that most patriotic of American sporting events, the Super Bowl. This was carried off at the end of the performance of Lady Gaga, known for her legions of queer fans (affectionately called 'Little Monsters') and queer friendly anthems such as 'Born this Way'.

Image 2: Lady Gaga performing at the 2017 Super Bowl 
As part of interrogating the ways in which the figuration of the insect or swarm becomes ambivalent in light of the militaristic 'drone swarm,' we can point to the limitations of evolutionary modes of reproduction rather than those that take up the posthuman challenges of digital technology and artificial intelligence in particular. Charlotte Perkins Gilman's utopian story of female equality and peacefulness in Herland uses insect-life as a positive model of society that is subject to unfair prejudice and uncomprehension from the forces of male (and, importantly, imperial and capitalist) superiority. Whether insect life presents a utopian or dystopian model depends on one's gendered subjectivity, but it is clearly presented as an ideal, and one possible in the absence of men. However, Herland is limited for thinking about our contemporary technological worlds in which life is folded into 'code' as a means of reproduction and communications: the model of reproduction is largely Darwinistic rather than the reassembly of code (see also Haraway, 1991; 1997) and, as in Gilman Perkins' political works, relies social evolutionary theory based on contemporary ethology to insist on the superiority of female led societies, as does Tiptree's story of insect-like women reproducing by cloning. These cannot speak to the posthuman condition of the drone swarm assemblage that incorporates what Hayles refers to as the cognisphere, or the "distributed cultural cognitions embodied both in people and their technologies" (Hayles 2006, p. 160). In other words, models of reproduction that rely upon Darwinistic or sexual reproduction are incompatible for the ways in which technologies of both reproduction and death-dealing are based on the code and increasingly, artificial intelligence. The figuration of the cyborg is germinal but insufficient for theorizing the complexities the posthuman figuration of the 'swarm' that characterizes the human/animal/technological matrix of swarming drones that depend on such distributed cognitive capacities.

This shift can be seen in the contrast between different versions of The Fly. David Cronenburg's 1986 remake of The Fly stars Geena Davis as plucky investigative journalist Veronica rather than the 1958 version's accommodating housewife and Jeff Goldblum as secretive scientist Seth Brundle turned "Brundlefly". Cronenburg's version represents the bodily horror of 'becoming-insect' in different and significant ways. Goldblum's character is transformed not into two separate human/fly hybrids as in the 1958 version, but, in keeping with the emphasis the powers and peril of DNA as the 'code' for life at the time, Seth and the fly were merged into a single being through a circuit that infected Seth through a wound in his back obtained while having sex with Davis's character. He too, became a monstrous-figure, caught in a state of transformation, of 'becoming-fly' rather than an 
instantaneous break that initially at least seems to give him 'better than human' powers. In this mode of becoming, traditional reproduction and phallocentric power become as irrelevant and detachable as the Brundlefly's penis (even if this change was instigated during heterosexual sex). The transformation into the alien, feminine 'other' does not, for at least a time, prove threatening. For Braidotti, this version of The Fly represents Deleure and Guattari's 'becoming-animal' is "a way of scrambling the master-code of phallocentrism and loosening its power over the body" (Braidotti, 2002, p.124). Braidotti's notion of 'becoming-insect' is about a materialist becoming outside of the human. However, this does not erase sexual difference but rather displace it (2002, p.169). In a related fashion, Elizabeth Grosz, inspired by Caillois' theories of insects, theorizes sex and the politics of sexual difference, outside of heteronormative reproductive sex to a more open mode of becoming (Parikka 2010) that can also be described as 'queer' (Grosz 1995), insofar as desire becomes about opening oneself to new encounters, new bodies, new affects.

As the swarm relies on modes of communication and reproduction outside of evolutionary and heteronormative frames, the use of such forms in 'swarm' warfare then participates in a kind of 'murderous inclusion' (Haritaworn, Kuntsman, and Posocco, 2014) and normalization of some queer subjects and bodies. A related development is the increasing ability for women, gay, lesbian, bisexual and transgender people to serve openly in the US military. The increased reliance on drones

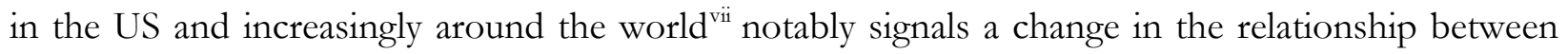
the military and masculinity, at least at the forefront of technology and war, with traditional military values associated with masculinity such as physical strength and courage under fire being less relevant to operational success (see for example Bayard de Volo, 2016). One source suggests has 17 percent of those assigned to drone activities at Creech Air Force base are female, an overrepresentation of women in the US military service in general (Manjikian, 2014). The US military has become more inclusive than ever in terms of gender and sexuality as it officially ended "Don't Ask, Don't Tell" in 2010 and to allow gay and lesbians to serve openly and it is also in a contested process of opening up combat positions to women. The US military also overturned its ban on transgender people serving on 30 June 2016, and will also provide transgender people with relevant medical care. The military can be said to have shifted from a site of patriarchal values and homophobia to a nominally 'ungendered' site in which women can be 'honorary men' (King, 2016) as well as a site of homonationalism (Puar 2007) in which the US is positioned as the site of exceptional sexual tolerance in opposition to the representations of Arab/Muslim sexuality as 
barbaric and perverse. One example of this form of 'murderous inclusion' can been seen in the reporting by The Daily Beast of a female drone pilot nicknamed 'Sparkle' because of bedazzled headset. Explaining her decorative choice, Sparkle reproduces the gendered, racialized logic of protection of women from Arab/Muslim men: "I use it to emasculate the enemy in the afterlife... Considering how they treat their women, I'm OK with rubbing salt in the wound" (Maurer, 2015). Here we see an example of a symbol of femininity — the frivolous and 'sparkly' - put into service of a racialized necropolitics of high-tech death dealing against dehumanized others, much as the figuration of the insect/swarm has been. While we see can see the drone swarm as a form of queer necropolitics that incorporates queer bodies and queer modes of signification into assemblages of racialized death-dealing; this does not exhaust the possibilities for the politics of the swarm.

\section{Futures}

Into this worldly figuration of the swarm, in which models of insect life are appropriated by the force of militarism into a tool for the sovereign management of other-than-human figurations of the 'swarm,' we may stumble upon re-visionings of the 'swarm' and insectoid life that affirm the transgressive possibilities in new alliances and assemblages with such figurations. ${ }^{\text {vii }}$ For example, Star Trek's Borg queen finds sister of sorts in black female musical icon Beyoncé. Beyoncé has embraced some of these insectoid metaphors with her most enthusiastic fans known as the 'Beyhive' and herself as 'Queen B' in an appropriation of this imagery for a matriarchal black feminist collective. ${ }^{\text {ix }}$ Beyoncé's recent performance at the 2017 Grammy awards, for example, embraced maternalgoddess imagery at the head of a group of black women and children recalls not only Halberstam's invocation of the fears of maternal reproductive power uncontrolled by racist or patriarchal forces but also afrofuturism in that it draws upon black cultural life to imagine and enact possible future worlds, especially in terms of imagining less constrained modes of black subjectivity (see Womack 2013, p. 9). Beyonce positioned her pregnant body as Madonna as a rebuke to the exclusion of black women from the Western cult of motherhood as well as the degradation of the reproductive black body while also wearing a gold grown and jewellery heralding perhaps a past, present, and future of black female power.

This example suggests that the possibilities of re-appropriation and re-configuration of the feminine, racialized threat of 'becoming-insect' that do not reproduce the racist, colonialist roots of the entomological sciences Gilman Perkins and others drew upon. Another example is Octavia Butler's 
trilogy of novels known as Lilith's Brood. Butler's work is also an example of afrofuturist literature as it reimagines themes from the transatlantic slave trade as alien abduction and uses this voyage and the resettlement on earth to explore the question of what it means to be human. After the earth's population was almost extinguished after an exchange of nuclear weapons, Lilith Iyapo, a black woman, is rescued and held in stasis by an alien species, the Oankali. The Oankali are consensusdriven, with an interspecies kinship structure mimic social insect formation, as well as queer interspectives sexuality (see also Cassel 2016). They have some physical resemblance to both insects and molluscs and initially cause the same fear and disgust that insects do. In both Lilith's Brood and Butler's award willing novella Bloodchild, insectoid aliens use human bodies for reproductive purposes. However, Butler uses these figures to explore the idea that intelligence and hierarchical social organization are not defining human characteristics but rather fatal flaws. In the worlds Butler creates, other beings exist and thrive outside of these characteristics and human interactions with these 'alien' others change human identity categories as well as desires.

Another such revisioning of 'becoming-insect' is a 2008 Mexican film, Sleep Dealer, directed by Alex Rivera. In a near-future dystopia, a swarm of drones operated by an employee of a corporation kills a man stealing water from a reservoir in Oaxaca, Mexico in order to water his drought-stricken crops. He is targeted on the basis of a radio receiver operated by his son-interpreted as 'terrorist activity in the area'. After his death, the man's son Memo travels to Tijuana to provide for his family and escape agrarian life. In Tijuana, Memo gets illegal implants called 'nodes' from an intriguing woman (Luz) that enable him to obtain work. The 'nodes' are considered a deviant bodily modification, associated with sex and sex work but one that allows many in Tijuana to survive in various forms of formal and informal employment.

[Image 3: Memo is wired into the global labour market]

[Image 4: Pods for wired-in labour extraction]

The trailers, which from the outside closely resemble the trailers from which drones are operated at Creech Air Force based outside of Los Vegas, consist of people hooked up via wires into the global 
economy. Connected via spider-web-like wires, the workers become wired-in zombies, building construction, driving cabs, and performing other kinds of unskilled labor in the United States via drones they control with their bodies while plugged in. While the border remains an omnipresent feature in Tijuana, here, the bodies of workers can remain on one side while their labor, enabled by robots they control, can travel the world. From here, the embodied sense of the operating the drones is made more visceral. This is in contrast to the heroic operators of the drone swarms, featured on the television as superheroes who kill 'evil-doers', who are connected via nodes as permanent fixtures in their bodies as policemen of the neoliberal order, patrolling the region for those who would steal water from the corporations who control the river, dam, and reservoir. In Sleep Dealer, both worlds of the drone are brought together: the high-tech wars against 'terrorists' and the automation of low-skill labor in the creation of networks of less-than-human bodies of precarious labor.

Meanwhile, Rudy, the 'all-American' drone pilot who, after some hesitation, launched the swarm of drones that killed Memo's father, comes to have a crisis of conscious. A Latino from a family proud of its history of military service, Rudy's experience bombing the purported 'aqua-terrorist' is a prescient forerunner of drone pilots such as Brandon Bryant ${ }^{\mathrm{x}}$ speaking out and working to undermine the war system based on their experiences witnessing the death and destruction they participate in. Using Luz's downloaded memories, he comes to Tijuana and locates Memo. Joining forces with Luz and Memo, Rudy 'plugs in' to the wires in Memo's trailer connecting him to the global network of information, labor and violence. He pilots his drone swarm to the dam that is controlling the supply of water to Oaxaca, damaging it and allowing water to flow freely to Memo's village.

The nodes enable Rudy, Luz, and Memo to 'connect directly to the global economy' through their nervous systems. The same system that connects the corporate state's violence in Rudy's body, allows Luz to download her memories of Memo, which allows Rudy to find Memo in Tijuana. Sleep Dealer ends with Memo and Rudy going their separate ways, each knowing they can't go home again. Memo's final monologue, translated into English, suggests a hopeful future: "a future with a past. If I connect. And fight”. Sleep Dealer presents a parable not only of the violence and repression of the 'drone swarm' and its roots in militarism and corporate control of resources, but of the power of 
connection that it enables for people, technologies, and the land to create new relations and new configurations.

\section{Conclusion}

Rather than serving as an inspiration for egalitarian feminist utopias, the metaphor and materiality of the swarm has been appropriated for distinctly dystopian war-fighting purposes. This form of 'homonationalism' (Puar 2007) that uses such queer, 'monstrous bodies' for purposes of maintaining control in racialized, necropolitical empire not only constitutes subjects as 'living dead' but creates such liminal, boundaries figures as the 'drone swarm' to maintain order. In considering the contemporary gender politics of the 'swarm,' Haraway's figure of the cyborg looms large for establishing the 'monstrous' body that is both a product of power relations and a possible technology through which a feminist and/or queer politics may resist. Haraway's cyborg is essential but incomplete for theorizations of contemporary politics of gender, bodies, and warfare because of its failure to move beyond the human/machine nexus to consider a 'human/animal/machine' nexus that contemporary political violence centered on the figure of the 'swarm' demands, despite Haraway's later work on companion species. A more robust appreciation from the uses of the insect and the swarm at the forefront of militarized systems of control as well their potential subversion for feminist/queer politics is called for in order to address the political challenges of the dystopian worlds of drone surveillance and destruction.

Like Memo from Sleep Dealer, or Lilith from Lilith's Brood, we cannot go home again to our separate colonies of insect life as an alternative to masculine and heterosexual domination, and racist, necropolitical worlds of violence, nor reject swarming figurations for prior models of liberal humanist agency. Perhaps we need not abandon the swarm as a useful figuration and inspiration from feminist utopias; its capacities for connections across borders, egalitarian modes of communication and coordination, not to mention the challenge it provides to heteronormative modes of sexuality and reproduction serve as potential inspirations that must now confront the racialized creation of necropolitical worlds of 'living dead' subject to elimination from these very swarm assemblages. The swarm forms a crucial figuration that informs both utopian and dystopian imaginaries. It remains for us to fight for futures enabled by the swarm in its multiple and complex manifestations that construct new possibilities for connection and world-building. 


\section{Bibliography}

Agamben, G., 1998. Homo Sacer. Sovereign Power and Bare Life. Stanford: Stanford University Press.]

Allinson, J., 2015. The Necropolitics of Drones. International Political Sociology 9(2): 113-27.

Anthes, E., 2013. The Race to Create 'Insect Cyborgs'. The Guardian, 17 February. Available at: www.theguardian.com/science/2013/feb/17/race-to-create-insect-cyborgs last accessed 05 September 2016].

Arquilla, J. and Ronfeldt, D., 2000. Swarming and the Future of Conflict. RAND Corporation. RAND/D8-311-OSD [RAND CORP Santa Monica CA, 2000]. Available at: www.rand.org/pubs/documented_briefings/DB311.html [last accessed 05 September 2016].

Axe, D., 2016. Commentary: Drones, Fighter Jets and the Future U.S. Air Force. Reuters, July 5, [last accessed 05 September 2016] Available at http://www.reuters.com/article/us-militaryairforce-commentary-idUSKCNOZLOFH.

Bayard de Volo, L. 2016. Unmanned? Gender Recalibrations and the Rise of Drone Warfare. Politics \& Gender 12(1), pp. 50-77.

Black, C., 2003. Press Conference for 2002 Annual Report "Patterns of Global Terrorism", 30 April. Available at: http://usinfo.state.gov/topical/pol/terror/ [last accessed 5 September 2016].

Braidotti, R., 2013. The Posthuman. Cambridge: Polity Press.

Braidotti, R., 2002. Metamorphoses. Towards a Materialist Theory of Becoming. Cambridge: Polity Press.

Bumiller, E., and T. Shanker. 2011. "Microdrones, Some as Small as Bugs, Are Poised to Alter War." The New York Times, June 19 Available at http://www.nytimes.com/2011/06/20/world/20drones.html. [last accessed 15 September 2015]

Butler, O. 2000. Lilith's Brood. New York: Warner.

Byman, D., 2013. Why Drones Work: The Case for Washington's Weapon of Choice. Foreign Affairs 92(July/August), p. 32. Available at http://www.foreignaffairs.com/articles/139453/daniel-byman/why-drones-work. [last accessed 05 September 2016]

Cassel, C. Bugs after the Bomb: Insect Representations in Postatomic American Fiction and Film. PhD University of Michigan 2016.

Cavallaro, J. and Sonnenberg, S. and Knuckey, S., 2012. Living Under Drones: Death, Injury and Trauma to Civilians from US Drone Practices in Pakistan. Stanford/New York: Stanford: 
International Human Rights and Conflict Resolution Clinic, Stanford Law School; New York: NYU School of Law, Global Justice Clinic. Available at: law.stanford.edu/wpcontent/uploads/sites/default/files/publication/313671/doc/slspublic/Stanford_NYU_LI VING_UNDER_DRONES.pdf [last accessed 05 September 2016].

Chamayou, G., 2015. A Theory of the Drone. Trans. J. Lloyd. New York: The New Press.

Chen, M.Y., 2012. Animacies: Biopolitics, Racial Mattering, and Queer Affect. Durham: Duke University Press.

Coeckelbergh, M., 2011. From Killer Machines to Doctrines and Swarms, or Why Ethics of Military Robotics Is Not (Necessarily) About Robots. Philosophy of Technology, 24(3), pp. 269-278.

Connolly, W. 2017. Facing the Planetary: Entangled Humanism and the Politics of Swarming. Durham, NC: Duke University Press.

Conner, M.C., 2014. Here Come the Swarming Drones. The Atlantic, 31 October. Available at: http:/ /www.theatlantic.com/technology/archive/2014/10/here-come-the-swarmingdrones/382187/ [last accessed 05 September 2016].

Creed, B., 1993. The Monstrous-Feminine: Film, Feminism and Psychoanalysis. London and New York: Routledge.

“David Cameron Criticised over Migrant 'Swarm’ Language.” 2015. BBC News, July 30, 2015, available at http://www.bbc.co.uk/news/uk-politics-33716501. [last accessed 20 September 2016].

Daggett, C. 2015. Drone Disorientations: how 'unmanned' weapons queer the experience of killing in war. International Feminist Journal of Politics 17(3), pp. 361-79.

Entomology Today. 2013. Do Female Praying Mantises Always Eat the Males? Entomology Today, 22 December 22. https://entomologytoday.org/2013/12/22/do-female-praying-mantisesalways-eat-the-males/. [last accessed 4 March 2017]

Feldman, K. P. 2011. Empire's Verticality: The Af/Pak Frontier, Visual Culture, and Racialization from Above. Comparative American Studies An International Journal 9(4): 325-41.

The Fly. 1958. Directed by Kurt Neumann. USA: Twentieth Century Fox

The Fly. 1986. Directed by David Cronenberg, USA: SLM Production Group.

Galloway, A. R., and E. Thacker. 2007. Exploit: A Theory of Networks. Minneapolis: University of Minnesota Press.

GOV.UK., 2016. Evaluation of Drones for Defence: Apply for Innovation Funding. Available at https://www.gov.uk/government/news/evaluation-of-drones-for-defence-apply-forinnovation-funding. [last accessed 30 September 2016] 
Grosz, E., 1995. Space, Time, and Perversion: Essays on the Politics of Bodies. New York and London: Routledge.

Halberstam J., 1991. Automating gender: postmodern feminism in the age of the intelligent machine. Feminist Studies 17(3): 439-460.

Halberstam J., 2011. The Queer Art of Failure. Durham: Duke University Press

Hambling, D., 2015. Swarm Troopers: How Small Drones Will Conquer the World. Archangel Ink.

Haraway, D., 1997. Modest_Witness@Second_Millennium.FemaleMan_Meets OncoMouse ${ }^{\mathrm{tm}}$.New York and London: Routledge

Haraway, D., 1991. A cyborg manifesto: Science, technology, and socialist-feminism in the late twentieth century. In Simians, Cyborgs and Women: The Reinvention of Nature, 149-181. New York and London: Routledge.

Haritaworn, J., 2015. Decolonizing the Non/Human. GLQ: A Journal of Lesbian and Gay Studies, 21(2-3), pp.210-213.

Haritaworn, J. and Kuntsman, A. and Posocco, S., eds., 2014. Queer Necropolitics. Abingdon: Routledge.

Hardt, M. and Negri, A., 2003. Empire. Cambridge, Mass: Harvard University Press.

Hastings, M., 2012 The Rise of the Killer Drones.” Rolling Stone. Available at http:/ / www.rollingstone.com/politics/news/the-rise-of-the-killer-drones-how-americagoes-to-war-in-secret-20120416. [Last accessed 30 September 2016]

Hayles, N.K., 2006. Unfinished Work: From the Cyborg to the Cognisphere. Theory, Culture and Society, 23(7-8), pp.159-66.

Hayles, N.K., 2005. My Mother was a Computer: Digital Subjects and Literary Texts. Chicago and London: University of Chicago Press.

Hayles, N.K., 1999. How We Became Posthuman: Virual Bodies in Cybernetics, Literature, and Informatics. Chicago: University of Chicago Press.

Jackson, P.T. and Nexon, D., 2003. Representation is Futile? American Anti-Collectivism and the Borg. In J. Weldes, ed. To Seek Out Other Worlds. Science Fiction and World Politics. New York: Palgrave Macmillan, pp. 143-167

King, A. 2016. The Female Combat Soldier. European Journal of International Relations 22(1), pp. 122-43.

Kosek, J., 2010. Ecologies of Empire: On the New Uses of the Honeybee. Cultural Anthropology, 25(4), pp.650-678. 
Kristeva, J., 1982. Powers of Horror: An Essay on Abjection. Translated by L. S. Roudiez. New York: Columbia University Press.

Lauro, S.J. and Embry, K., 2008. A Zombie Manifesto: The Nonhuman Condition in the Era of Advanced Capitalism. boundary 2, 35(1), pp. 85-108.

Lewis, M. W., 2013. Drones: Actually the Most Humane Form of Warfare Ever. The Atlantic, August 21. [last access 05 September 2016] available at http:/ /www.theatlantic.com/international/archive/2013/08/drones-actually-the-mosthumane-form-of-warfare-ever/278746/.

Manjikian, M., 2014. Becoming Unmanned. International Feminist Journal of Politics, 16(1), pp.4865.

Maurer, K., 2015. She Kills People From 7,850 Miles Away. The Daily Beast, October 18. http:/ /www.thedailybeast.com/articles/2015/10/18/she-kills-people-from-7-850-milesaway.html. Last accessed 30 September 2016.

Mbembe, A., 2003. Necropolitics. Public Culture, 15(1), pp. 11-40.

Murphy, G.J., 2008. Considering Her Ways: In(ter)secting Matriarchal Utopias. Science Fiction Studies, 35(2), pp. 266-280.

New American Foundation. 2016. World of Drones. Available at http:/ / securitydata.newamerica.net/world-drones.html 2016. [last accessed 30 September 2016]

The New Inquiry. 2016. "Bugs" 54. Available at http://thenewinquiry.com/features/the-newinquiry-vol-54-bugs/ [last accessed 30 September 2016]

Parikka, J., 2010. Insect Media: An Archeology of Animals and Technology. Minneapolis: University of Minnesota Press.

Perkins Gilman, C., 2015[1915]. Herland and the Yellow Wallpaper. London: Vintage.

Puar, J.K., 2007. Terrorist Assemblages: Homonationalism in Queer Times. Durham: Duke University Press.

Reddy, C., 2011. Freedom with Violence: Race, Sexuality, and the US State. Durham: Duke University Press.

Rodgers, D. M., 2008. Debugging the Link between Social Theory and Social Insects. Baton Rouge: Louisiana State University Press.

Scharre, P., 2014. Robotics on the Battlefield Part II: The Coming Swarm. Center for a New American Security, 15 October. Availabe at: 
http://www.cnas.org/sites/default/files/publications-

pdf/CNAS_TheComingSwarm_Scharre.pdf [last accessed 05 September 2016].

Sedgwick, E. K., 1993. Tendencies. Durham: Duke University Press.

Shaviro, S., 1995. Two Lessons from Burroughs. In J. Halberstam and I. Livingston, eds. Posthuman Bodies. Bloomington and Indianapolis: Indiana University Press, pp.38-56.

Singer, P.W., 2009. Wired for War. The Robotics Revolution and Conflict in the $21^{\text {st }}$ Century. New York: The Penguin Press.

Sleep Dealer, 2008 [film]. Directed by Alex Rivera. Mexico: Likely Story, This is That Productions.

Strawser, B. J., 2010. Moral Predators: The Duty to Employ Uninhabited Aerial Vehicles.” Journal of Military Ethics 9(4): 342-68.

Stryker, S., 1994. My Words to Victor Frankenstein Above the Village of Chamounix: Performing Transgender Rage. GLQ: A Journal of Lesbian and Gay Studies 1(3) pp. 237-254

Stryker, S. 2015. Transing the Queer (In)human 227-230 in Munoz, J. E., J. Haritaworn, M. Hird, Z. I. Jackson, J. K. Puar, E. Joy, U. McMillan, et al. “Theorizing Queer Inhumanisms." GLQ: A Journal of Lesbian and Gay Studies 21, no. 2-3: 209-48.

Thacker, E., 2004a. Networks, Swarms, Multitudes: Part One. CTHEORY, 18 May. Available at: www.ctheory.net/articles.aspx?id=422 [last accessed 05 September 2016].

Thacker, E., 2004b. Networks, Swarms, Multitudes: Part Two. CTHEORY, 18 May. Available at: www.ctheory.net/articles.aspx?id=423) [last accessed 05 September 2016].

Thacker, E., 2011. Necrologies, Or the Death of the Body Politic. In P.T. Clough and C. Willse, eds. Beyond Biopolitics: Essays on the Governance of Life and Death. Durham: Duke University Press, pp.46-64.

Thielman, S. 2015. Robot Swarms: Scientists Work to Harness the Power of the Insect World. The Guardian, September 18. Available at

https://www.theguardian.com/technology/2015/sep/18/robot-swarms-drone-scientistshive-mentality. [last accessed 20 September 2015]

Tiptree Jr., J., 1989[1976]. Houston, Houston, Do You Read? New York: Tor.

Weber, C., 2016. Queer International Relations: Sovereignty, Sexuality and the Will to Knowledge. New York, NY: Oxford University Press.

Weizman, E., 2011. The Least of All Possible Evils: Humanitarian Violence from Arendt to Gaza. London; New York: Verso.

Wilcox, L., 2017. Embodying Algorithmic War: Gender, Race, and the Posthuman in Drone Warfare. Security Dialogue. 48(1) pp. 11-28. 
Wilcox, L., 2015. Bodies of Violence: Theorizing Embodied Subjects in International Relations. New York and Oxford: Oxford University Press.

\author{
Womack, Y. 2013. Afrofuturism: The World of Black Sci-Fi and Fantasy Culture. Chicago: Chicago \\ Review Press.
}

\footnotetext{
${ }^{i}$ Many thanks to the editors and anonymous reviewers for their insightful comments and support of this project. Thanks also to Stefanie Fishel and audiences at the International Studies Association, 2015, the University of Cambridge Centre for Gender Studies, and the Centre for Gender Studies, SOAS for critical engagement as well. I'm also grateful to AnneKathrin Weber for assistance in preparing the manuscript for publication.

ii This is especially true in the post-nuclear world: for Aristotle, Spencer, and others, insects have played a more diverse role as metaphor and inspiration for communal life. See Braidotti, 2002, p.148, Parikka, 2010 and Rodgers, 2008 for more examples.

iii Similar 'RoboRoaches' can be bought and trained as a hobby (Anthes, 2013).

iv For examples of the military slang 'bug splat' see Hastings, 2012.

v The 'bug splat' phrase was also dramatized by an art project called 'Not a Bug Splat' enacted in Northern Pakistan to show a large-scale image of a child with the intention that it is big enough to drone operators to view. See https://notabugsplat.com/.

vi Thanks to Gina Heathcote for this point.

vii The New America Foundation lists nineteen countries that have acquired weaponised drone technology including the US, UK, China, Israel, Pakistan, Iran, Iraq, Nigeria, Somalia and South Africa (New America Foundation 2016).

viii In his 2017 book released as this piece was in final revisions, Bill Connolly also suggests the modes of movement, affectivity, and communication in bees as an inspiration for political action.

${ }^{\text {ix }}$ Many thanks to an anonymous reviewer for suggesting the relevance of Beyoncé's work and celebrity in relation to this question.

x Brandon Bryant was a drone pilot tasked with targeted killings and is now an outspoken critic of drone warfare. He has been featured in major exposes of the US's use of lethal force in Der Speigel and GQ, in Tonje Hessen Schei's 2016 documentary Drone, and has also testified at the United Nations.
} 